\title{
Screening some Common Molecular Markers and a Desaturase Marker, Linked to Sex Pheromone Biosynthesis, in Three Z-Strain and an E-Strain Populations of the European Corn Borer, Ostrinia nubilalis, Occurring in Central Europe
}

\author{
G. BOZSIK ${ }^{1}$, A. LAKATOS ${ }^{1}$, G. SZŐCS ${ }^{1 *}$ and I. TÓBIÁS ${ }^{2}$ \\ ${ }^{1}$ Department of Zoology, Plant Protection Institute, Centre for Agricultural Research, \\ Hungarian Academy of Sciences, H-1022 Budapest, Herman Ottó út 15. Hungary \\ ${ }^{2}$ Department of Pathophysiology, Plant Protection Institute, Centre for Agricultural Research, \\ Hungarian Academy of Sciences, H-1022 Budapest, Herman Ottó út 15. Hungary
}

(Received: 10 December 2018; accepted: 15 February 2019)

The European corn borer moth, (ECB), Ostrinia nubilalis (Lepidoptera: Crambidae, Pyraustinae) is one of the most destructive pests of maize worldwide. ECB has two pheromone-strains, separated by specific ratios of isomers of E- and Z11-tetradecenyl acetates (E11- and Z11-14Ac), but appearing morphologically identical. Accordingly, E- and Z-ECB pheromone traps are available for the respective populations for practical monitoring of the flight, however, traps for Z-strain are unreliable for practical usage in some parts of Central-Europe. E- and Z-ECB populations occur in sympatry in some areas, while in allelopatry in other areas. Determining the strains before the flight of adults, when difference in the composition of their respective pheromones is manifested, would be of practical interest for early warning. In addition to the known fatty-acyl-reductase (FAR) marker, further markers would allow more comprehensive studies. We screened the following common markers for mitochondrial and nuclear DNA regions: partial cytochrome c oxidase I (COI), cytochrome B (CytB), the second spacer of the internal transcribed spacer (ITS2), Elongation factor 1a (EF1a) and actin gene (Act). In addition, a marker of the $\Delta 11$-desaturase gene (11desat), linked to biosynthesis of female-produced sex pheromone, was also included, because we reported earlier a differential expression for this site. Three Z-ECB populations locating at distant sites within Hungary, an area where only Z-strain occurs, and an E-ECB population in Slovenia, known as the closest-occurring E-strain, were included into the study. Separate laboratory colonies were established from each population, and $\mathrm{F}_{1}$ generations were sampled to verify the identity of pheromone strains, by analysing the composition of sex pheromone by gas chromatography linked to an electroantennographic detector (GC-EAD). Molecular studies were conducted using specimens taken from the $\mathrm{F}_{2}$ generations. Results of genetic studies showed that there were no differences between the $\mathrm{Z}$ and $\mathrm{E}$ populations for the common markers. In contrast to this, several nucleic acid changes (11 nt in 4 positions) were found between the three Z-populations (Hungary) and the E-population (Slovenia) in the desaturase marker. Further study is required to reveal whether the differences found in this study are consistent across E-populations, thus making these markers suitable for diagnostic purposes.

Keywords: Sex pheromone strains, cryptic sibling species, maize, pest, moth, diagnostic DNA marker, early warning, larval stage.

*Corresponding author; email: szocs.gabor@agrar.mta.hu 
The European corn borer moth (ECB), Ostrinia nubilalis Hübner 1796 (Lepidoptera: Crambidae, Pyraustinae) is one of the most important pests of maize and several other crops worldwide (CABI Invasive Species Compendium), with significant impact on maize particularly in Europe (Pronko, 2011). ECB has two cryptic pheromone strains (Kochansky et al., 1975), isolated by specific ratios of isomers of E- and Z11-tetradecenyl acetates (E11-14Ac and Z11-14Ac), respectively. The Z-strain communicates with a mixture of these isomers containing the Z-isomer, as the major constituent of the blend, while the reverse ratio of the same isomers is used by the E-strain. The spread, host plant preferences and economic importance of these respective strains were intensively studied in Europe (Schmitz, 1999; Pelozuelo et al., 2004). The E-strain moved northwards in Europe and reached Scandinavia (Lehmhus et al., 2012). However, little is known about the actual areas of the respective strains. More recent data were needed to track the actual appearance of respective strains for risk assessment in maize. This is because strains are different in their preferences to secondary host plants, especially to some common weed species associated to maize field, which could be potential sources of re-infestations of maize (Schmitz, 1999; Pelozuelo et al., 2004).

However, strains are morphologically identical. Pheromone traps baited with the respective strain-specific lures are expected to attract male moths of the corresponding strains selectively. However, the field performance of these traps is, for unknown reasons, rather poor in most parts of central Europe, therefore pheromone traps are not suitable for practical monitoring (Szőcs and Babendreier, 2011). The chemical analysis of the female-produced pheromone is a time-consuming procedure, requires instrumentation and qualified human resources, therefore not feasible for practical application. Moreover, identification of strains would be of much greater importance at larval stage, for early warning preceding the flight period. For this, readily available diagnostic DNA molecular markers could suit well.

In Hungary only Z-ECB strain is known to occur (Peña et al., 1988), however, near to the Southern border of Hungary, for example in Slovenia, E-strains were also found (Rak-Cizej et al., 2014). There is a risk that E-strain populations would migrate towards North and reach Hungary, as well. Therefore, it would be of practical importance to detect the occurrence of E-strains in Hungary, as soon as they arrive.

The search for pheromone strain-specific molecular markers revealed so-far only subtle differences, with the only notable exception being the sex-linked Tpi gene (Dopman et al., 2005). Even this difference in the Tpi gene needs care in practical exploitation, as although there is $99 \%$ uniformity within the E-strain, the similarities within the Z-strain were found to be only $74 \%$.

Comparing some intronic DNA sequences of several olfactory receptor-encoding genes revealed "nearly fixed differences between strains" (Lassance et al., 2011). A further possibility is offered by the allelic variation in a fatty-acyl reductase enzyme gene, expressed in the pheromone gland (pgFAR) (Lassance et al., 2010). In this study Z- and E-ECB populations from several European countries (France, Slovenia and Hungary) were involved, therefore the practical implementation of these findings for recognition of strains across Europe is awaited.

Coates et al. (2013) identified three single nucleotide differences in ECB pgFAR, which difference correlated more than $98 \%$ to strain-identity. This difference can obviously be used as a reliable marker, although finding some more pronounced differences would enhance the diagnostic value. 
Another approach was offered by the differential expression of a $\Delta 11$-desaturase transcript in ECB larvae (Király and Szőcs, 2009). Apart from FAR, $\Delta 11$-desaturase is the other key enzyme in pheromone biosynthesis of ECB (Roelofs et al., 2002), therefore this approach seems to be also promising. However, further studies are needed to reveal how strongly this differential marker is associated to various E- and Z-populations, occurring across larger areas. If differences responsible for this diagnostic expression were also found at DNA level, this could provide a method more easily applicable in practice. In order to investigate this latter possibility, we sequenced the corresponding part of the genome using the same primers described in Király and Szőcs (2009), and looked for selective markers for the Z- and E-strains of ECB. Looking for further possible DNA differences, some common markers, widely used for distinguishing between taxonomically closely related species, or between sibling species, such as COI, CytB, ITS2, EF1a, and an actin-locus for reference, were also included in this study.

\section{Materials and Methods}

\section{Insects}

ECB-Z pheromone strain: Three populations, occurring at three geographical regions of Hungary, were sampled in this study. The population at Kéty (Tolna county, SW Hungary) has two flights per season, under that warm and humid climate. The population at Hódmezővásárhely (Csongrád county, SE Hungary) has also two flights per season, since the climate is similarly warm, however, dry. In contrast to these, the population at Romhány (Nógrád county, N Hungary) has only one flight per season under that climate, which is colder than those of the other two regions, while humid.

ECB-E pheromone strain: An E-population at Žalec, Slovenia (courtesy of Dr. M. Rak-Cizej) was included in the study. This population was chosen, as it was the nearest-occurring E-population to Hungary.

Sampling protocol: Mature, overwintering larvae or pupae were collected from stalks of maize during winter of 2010-2012. Collected larvae/pupae were allowed to overwinter under ambient conditions in an outdoor-greenhouse of our institute. In spring, they were transferred into separate rearing rooms, under $26^{\circ} \mathrm{C}$ temperature and $18 / 6$ hours light/dark photo period, and adults were let to emerge. $\mathrm{F}_{1}$ generation was reared on artificial diet (Nagy, 1970) under the above-mentioned long-day laboratory conditions. Emerging adult females were sampled to verify strain-identity (see below), why the rest of the populations were used to establish the next generation. Molecular studies (see below) were conducted on randomly selected specimens, taken from the $\mathrm{F}_{2}$ generation. Each culture was kept under strict isolation, in well-separated rearing rooms to prevent incidental mixing.

\section{Verifying pheromone strains}

Pheromone strains were identified by analysing pooled ovipositor tip extracts of five calling females, extracted in $n$-hexane, by means of gas chromatography coupled to an electroantennographic detector (GC-EAD) (GC: 6890 N, Agilent Technologies Inc., 
Santa Clara, CA, USA, column: DB-Wax $30 \mathrm{~m} \times 0.32 \mathrm{~mm} \times 0.25 \mu \mathrm{m}$ film thickness, $\mathrm{J}$ and W Scientific; EAD: MP15 micromanipulator connected to a IDAC 232 amplifier, Syntech, Kirchzarten, Germany). Injections were made in split/splitless mode, the injector temperature was $220{ }^{\circ} \mathrm{C}$ and the temperature program was as follows: $60{ }^{\circ} \mathrm{C} / 1 \mathrm{~min}$, then $10{ }^{\circ} \mathrm{C} / \mathrm{min}$ to $220^{\circ} \mathrm{C}, 220^{\circ} \mathrm{C} / 5 \mathrm{~min}$. The temperature of the flame ionization detector was set to $225^{\circ} \mathrm{C}$. The transfer line for the antennal detector was set also to $225^{\circ} \mathrm{C}$. The pheromone components in the extracts were identified based on their respective retention times (RT), as compared to corresponding RTs of synthetic E11-14Ac and Z11-14Ac, injected together, along with saturated decyl acetate (S10Ac), as internal standard. The presence of E- and Z11-14Ac in the extracts was further corroborated by the antennal responses (using isolated, strain specific male antennae, as antennal detector). The amounts of E11-14Ac and Z11-14Ac in the extracts were calculated according to the respective peak areas, in the FID-trace.

\section{DNA-based identification}

Total DNA was extracted from a part of abdomen in each individual (minimum number of 15 males and 15 females, per populations, respectively, except "Romhány" population, were altogether 10 specimens were taken) using REDExtract-N-Ampl ${ }^{\mathrm{TM}}$ Seed preparation PCR Kit (Sigma) according to the manufacturer's instruction with a slight modification. A piece of abdomen was placed in a sterile Eppendorf tube, covered with $100 \mu 1$ extraction solution and crushed. It was then incubated at $55^{\circ} \mathrm{C}$ for 10 minutes, followed by 3 minutes incubation at $95{ }^{\circ} \mathrm{C}$, and then the same quantity $(100 \mu 1)$ of neutralization solution was added to the sample and mixed by vortex mixer. One micro liter from this mixture was used for polymerase chain reaction (PCR) experiments. Amplification was performed in volume of $25 \mu \mathrm{l}$ of PCR puffer $(10 \mathrm{mM}$ Tris- $\mathrm{HCl}, \mathrm{pH} 9.5,2.5 \mathrm{mM}$ $\mathrm{MgCl}_{2}, 50 \mathrm{mM} \mathrm{KCl}, 0.1 \%$ Triton X100) containing $100 \mathrm{ng}$ each of dATP, dCTP, dGTP and dTTP and $0.1 \mathrm{nM}$ each sense and antisense primers and $5 \mathrm{U}$ Taq polymerase (Invitrogen). The mitochondrial gene (COI and Cyt B), nuclear protein coding gene Elongation Factor $1 \alpha$ (EF1a), actin gene, 11-desaturase gene and nuclear ribosomal DNA ITS2 region were amplified (Table 1). A standard thirty-five PCR programme cycles were performed (Eppendorf Mastercycler gradient) with the following parameters: denaturation $95{ }^{\circ} \mathrm{C}$ for $4 \mathrm{~min}$, followed $94{ }^{\circ} \mathrm{C}$ for $30 \mathrm{~s}, 50{ }^{\circ} \mathrm{C}$ for $20 \mathrm{~s}$ and $72{ }^{\circ} \mathrm{C}$ for $90 \mathrm{~s}$ with final extension at $72^{\circ} \mathrm{C}$ for $10 \mathrm{~min}$. The annealing temperatures were $48^{\circ} \mathrm{C}$ for amplification of Elongation Factor and 11-desaturase gene, $52^{\circ} \mathrm{C}$ for actin gene. After electrophoresis in $1 \%$ agarose gel, PCR products were detected and documented in BioDoc-It ${ }^{\mathrm{TM}}$ system (Table 1).

\section{Cloning}

The PCR products were cloned into pJET1.2/blunt cloning vector (Fermentas). The recombinant plasmids were transformed into Escherichia coli DH5 $\alpha$ competent cells. All cloning steps were based upon standard molecular biology protocols (Sambrook et al., 1989). The recombinant plasmids isolated from selected colonies were sequenced using pJET1.2 forward or reverse sequencing primers by an automated DNA sequencer (Ap- 
Table 1

Molecular markers tested in this work, name of region targeted, name of primers, sequence of primers and reference

\begin{tabular}{|c|c|c|c|}
\hline Locus name & Primer name & Primer sequence $5^{\prime}-3$ ' & Reference \\
\hline \multirow[t]{4}{*}{ COI } & C1-J-1718 & ggaggatttggaaattgattagttcc & Loxdale and Lushai, 1998 \\
\hline & C1-N-2191 & cccggtaaaattaaaatataaactttc & \\
\hline & $\mathrm{mtD}-7.2 \mathrm{~F}$ & attaggagchcchgayatagcatt & Brunner et al., 2002 \\
\hline & $\mathrm{mtD}-9.2 \mathrm{R}$ & caggcaagattaaaatataaacttctg & \\
\hline \multirow[t]{2}{*}{ CytB } & CB-J10747 & tgtcgagatgtaaattatggntg & Stewart and Beckenbach, 2005 \\
\hline & CB-N11526 & ttcaactggtcgrgctccaatyca & \\
\hline \multirow[t]{4}{*}{ ITS2 } & CAS5p8sFc & gcgaacatcgacaagtcgaacgcacat & Kim and Lee, 2008 \\
\hline & CAS28sB1d & ttgttttcetccgcttattaatatgcttaa & \\
\hline & $28 \mathrm{Z}$ & agactccttggtccgtgtttc & Moritz et al., 2001 \\
\hline & P1 & atcactcggctcgtggatcg & \\
\hline \multirow[t]{4}{*}{ EF1a } & M3 & cacatyaacattgtcgtsatygg & Downie and Gullan, 2004 \\
\hline & RcM44.9 & cttgatgaaatcyctgtgtcc & \\
\hline & M51.9 & cargacgtatacaaaatcgg & Downie and Gullan, 2004 \\
\hline & RcM53.2 & gcaatgtgrgcigtgtggca & \\
\hline \multirow[t]{4}{*}{ Actin } & Act-1 & tgggacgatatggaiaaiatctggca & Voigt and Wöstemeyer, 2000 \\
\hline & Act-2 & gtccciatctacgaigg & \\
\hline & Act- $4 \mathrm{r}$ & tcitcgtattcttgcttigaiatccacat & \\
\hline & Act-5r & ttagaagcacttyctgtg & \\
\hline \multirow[t]{2}{*}{ 11desat } & 11desatforw & cgaggattcttctattcacat & Király and Szőcs, 2009 \\
\hline & 11desatrev & tccgacctactctttatcatttctt & \\
\hline
\end{tabular}

plied Biosystem Gene Analyzer 3100). Sequence comparisons were performed using Wisconsin Package version 10.0 Genetic Computer Group (GCG) sequence analysis software (Devereux et al., 1984).

\section{Results}

\section{Verifying pheromone strains}

Synthetic Z11-14Ac showed baseline separation from E11-14Ac in the gas chromatographic analysis. The ratio of Z- and E11-14Ac, the two pheromone-components in each extracts prepared from Hungarian ECB populations, showed the prevalence of the Z-isomer, typical to Z-ECB strain. In contrast to this, the population from Slovenia showed a reverse ratio, typical to E-strain.

\section{Comparing PCR products - similarities between ECB populations}

PCR products of females and males of E- and Z-strains of Ostrinia nubilalis showed highly similar patterns, respectively in all primer pairs. Seven of the 10 pairs of 
primers tested gave single PCR products, while Act- 2 and Act-5r actin gene primers and primers of the EF1a amplified two and four products, respectively. The sizes of the amplicons were: CI-J-1718 - C1-N-2191 (524 bp) and the mtD-7.2F - mtD-9.2R ( 500 bp) regions of COI, CAS5p8sFc - CAS-28sB1d (584 bp), the 28-Z - P1 ( 1700 bp) regions of ITS2, Act-2 - Act-4r (605 bp) a part of actin gene, 11desatforw and 11desatrev (1472 bp) apart from 11-desaturase gene and 825 bp for CytB region. Five markers (CI-J-1718 - C1-N-2191 COI, CytB, Act-2 and Act-4r actin gene, 11-desaturase and CAS5p8sFc CAS-28sB1d ITS2) were selected from the initial screening for further sequencing. The PCR products of females and males of E- and Z-strains of $O$. nubilalis were cloned and sequenced except for the actin gene where products only from males of E- and Z-strains were cloned. Sequences of each marker were compared with each other and some available sequences in the GenBank.

\section{Table 2}

Accession numbers for sequences deposited in the GenBank for markers of sexes and Z- and E-pheromone strains of the European corn borer, ECB, Ostrinia nubilalis

\begin{tabular}{llllll}
\hline Pheromone strain-sex & COI & CytB & ITS2 & Desat & Actin \\
\hline Z-female & MK513456 & MK513455 & MK480497 & MK493122 & \\
E-female & MK513457 & MK513454 & MK480498 & MK493121 & \\
Z-male & MK513459 & MK513452 & MK480499 & MK493120 & MK513460 \\
E-male & MK513458 & MK513453 & MK480500 & MK493119 & MK513461 \\
\hline
\end{tabular}

Sequences of the products gained in this study were deposited in the GenBank, under the accession numbers shown in (Table 2).

Similarities of sequences of CytB mitochondrial DNA fraction of E- and Z-strains of $O$. nubilalis (compared DNA size $825 \mathrm{nt}$ ) were $99.0-100 \%$, and that of sequences in the GenBank 98.9-99.8\% (Af442957 - COATES et al. 2005, Fj435427 - YANG et al. 2008, unpublished).

Similarities of sequences of mitochondrial gene cytochrome oxidase I (COI) of E- and Z-strains of $O$. nubilalis (compared DNA size $524 \mathrm{nt}$ ) were 99.6-100\%, and that of sequences in the GenBank 98.2-99.6\% (Ay649321 - AGUSTI et al. 2005; Af442957 COATES et al. 2005; Af321877 - COATES et al. 2000, unpublished).

Similarities of ITS2 ribosomal DNA region of E- and Z-strains of $O$. nubilalis (compared DNA size $584 \mathrm{nt}$ ) were 98.9-100\%, and that of a sequence in the GenBank 99.2-99.7\% (Af349036 - COATES et al. 2001, unpublished).

Sequence identity of actin gene between the E- and Z-strains was $99.7 \%$. In the GenBank there is no data available on the actin gene of Ostrinia nubilalis. The closest identity is to that of Cydia pomonella (AY524976) of $92 \%$.

The sequence analysis of tested molecular markers showed high conservation and identity in all cases. The intraspecific variation was no more than $1-2 \%$, regardless the geographical origin. The results indicated that sequence variation of different individuals within the same pheromone strain were higher than between the two pheromone strains in respect of the above common markers. 
Similarities of 11 desaturase gene region of E- and Z-strains of $O$. nubilalis (compared DNA size $1472 \mathrm{bp}$, except ZO $1541 \mathrm{bp}$ ) was also as high as 96.7-99.5, and that of sequences in the GenBank 96.4-99.8\% (EF113391 and EF113392 - XUE et al. 2007). In this case slightly higher variation was found, as compared to the above common markers, however, these subtle differences on their own would not have any basis for discrimination, especially not, because it could be explained that several cryptic 11-desaturase genes are involved in the pheromone biosynthesis. Indeed, two distinct clades of $\Delta 11$-desaturase have been described for $O$. nubilalis which do not sort with pheromone strains (Geiler and Harrison, 2010).

\section{Comparing PCR products - differences between ECB populations}

In contrast to $\mathrm{CytB}, \mathrm{COI}$, ITS2 where the subtle differences appeared at various sites, several nucleic acid changes (11 nt in 4 positions) in the desaturase marker were consistent within all of the three Z-strains (Hungary) (both males and females), but different from that of the E-population (Slovenia) (both sexes). The sequence in the three Z-strains (Hungary) was identical to that reported in the Genbank for a Z-strain (USA) (ef113392 - XUE et al. 2007).

These differences were as follows (numbered as in NCBI accession number ef113392): GATA and GCAAC nucleotides inserts between 316-317 and 563-564, respectively, at position 332 A changed by $\mathrm{G}$ and at $382 \mathrm{C}$ replaced by $\mathrm{G}$.

\section{Discussion}

The widely-used markers (CytB, COI, ITS2, EF1a) tested in this work did not differentiate between the E- and Z-strains of $O$. nubilalis. Also, no diagnostic marker was found using these markers.

In contrast to this, the marker for $\Delta 11$-desaturase, originally described as an expression marker (Király and Szőcs, 2009), separated in this study all three Z-strains from the topographically closely occurring E-strain. This indicates that this marker appears not only at expression, but is present in the DNA, as well. However, studies should be extended to more ECB populations, especially to more E-ECB populations, to reveal whether the above-mentioned marker is indeed strain-specific. In this respect, comparing E- and Z-ECB populations, occurring in sympatry could serve pivotal evidence. The 11desat enzyme acts before the bifurcation step leading to strain specific components (Lassance, 2016), which makes unlikely that it were selectively linked to strain-specific pheromone intermediates. However, either one/some of the alleles or cryptic pseudogenes of 11dest should be selectively associated to strains. This could be possible, as several cryptic 11desat and also 14desat were reported in ECB (Xue et al., 2007).

There are only few markers reported in the literature for separating E- and Z-strains. A possibility is offered by specific markers, based on allelic variation in a fatty-acyl reductase, described by Lassance et al. (2010, 2011). This method has already been successfully used to determine the first appearance of the Z-strain in Southern-Sweden from a very few larvae (Lehmhus et al., 2012). However, the feasibility of using this method for 
various populations, located across the wide distribution range of $O$. nubilalis still has to be verified in more detail. A more recently described method (Coates et al., 2013), based on single nucleotide polymorphism in a fatty-acyl reductase, if applies also to European populations, offers a further possibility.

The diagnostic value of the desaturase marker found in this study needs also further studies. More ECB populations, especially that of the E-strain, should be included in the survey to see how consistent the differences are across various ECB populations. Furthermore, specificity of the desaturase marker has to be checked, as well, as pseudogenes are known to occur. Xue et al. (2007) reported several novel sex pheromone desaturases in ECB, generated through gene duplication and retroposon fusion. In a detailed study Geiler and Harrison (2010) revealed divergent allelic classes for $\Delta 11$-desaturase in ECB. They concluded that this enzyme does not contribute to the reproductive isolation between pheromone strains, and may reflect either shared ancestral polymorphism, or recent hybridization between strains. Focusing on host plant races of ECB in relation to four nuclear loci (linked to enzymes of carbohydrate metabolism, pheromone binding protein and flight muscle), Malausa et al. (2007) concluded that reproductive isolation between "maize-Z" and "mugwort-hop-E" race is still incomplete, nevertheless divergence between host races of French ECB populations roots back long before the introduction of corn into Europe. As they pointed out, this slow divergence under high gene flow fits to the speciation of host plant races of the larch budworm, Zeiraphera diniana Guenée (Lepidoptera: Tortricidae), described by Emelianov et al. (2004). Not only in desaturase markers, but also in other regions, especially in microsatellite loci of ECB varies the number of alleles. Dalecky et al. (2006) studied 13 microsatellite loci in ECB for polymorphism and found that the number of alleles per locus ranged from one to twelve.

At present, our findings on the representation of the 11desat marker at DNA level may facilitate further studies for a reliable diagnostic method for molecular identification of pheromone strains of ECB.

\section{Acknowledgements}

The valuable comments of several anonymous reviewers of earlier versions of this paper are greatly acknowledged. Sincere thanks are due to Dr. MAGDA RAK-CIZEJ (Slovenian Institute of Hop Research and Brewing, Žalec, Slovenia) for collecting ECB larvae of E-strain. Thanks are do to Dr. CHRISTOPHE GADENNE (INRA-Université d'Angers, France) and Dr. CSABA CSUZDI (Department of Zoology, Eszterházy Károly College, Eger, Hungary) for their valuable comments on an earlier version of this manuscript. This work was in part financially supported by OTKA K100421.

\section{Literature}

Agusti, N., Bourguet, D., Spataro, T., Delos, M., Eychenne, N., Folcher, L. and Arditi, R. (2005): Detection, identification and geographical distribution of European corn borer larval parasitoids using molecular markers. Molecular Ecology 14, 3267-3274.

Brunner, P. C., Flemming, C. and Frey, J. E. (2002): A molecular identification key for economically important thrips species (Thysanoptera: Thripidae) using direct sequencing and PCR-RFLP-based approach. Agricultural and Forest Entomology 4, 127-136.

CABI Invasive Species Compendium. https://www.cabi.org/isc/datasheet/46129 
Coates, B. S., Sumerford, D. V., Hellmich, R. L. and Lewis, L. C. (2005): Partial mitochondrial genome sequences of Ostrinia nubilalis and Ostrinia furnacalis. International J. Biol. Sci. 1, 13-18.

Coates, B. S., Johnson, H., Kim, K. S., Hellmich, R. L., Adel, C. A., Mason, C. and Sappington, T. H. (2013): Frequency of hybridization between Ostrinia nubilalis E- and Z-pheromone races in regions of sympatry within the United States. Ecology and Evolution 3, 2459-2470.

Dalecky, A., Bogdanowicz, S. M., Dopman, E. B., Bourguet, D. and Harrison, R. G. (2006): Two multiplex sets of eight and five microsatellite markers for the European corn borer, Ostrinia nubilalis Hübner (Lepidoptera: Crambidae). Molecular Ecology Notes 6, 945-947.

Devereux, J., Haeberli, P. and Smithis O. (1984): A comprehensive set of sequence analysis program for the VAX. Nucleic Acids Research 12, 287-395.

Dopman, E., Pérez, L., Bogdanowicz, S. M. and Harrison, R. G. (2005): Consequences of reproductive barriers for genealogical discordance in the European corn borer. Proc. of the National Academy of Sciences of USA 102, 14706-14711.

Downie, D. A. and Gullan, P. J. (2004): Phylogenetic analysis of mealybugs (Hemiptera: Coccidea: Pseudococcidae) based on DNA sequences from three nuclear genes, and a review of the higher classification. Systematic Entomology 29, 238-259.

Emelianov, I., Marec, F. and Mallet, J. (2004): Genomic evidence for divergence with gene flow in host plant races of the larch budmoth. Proc. of the Royal Society B-Biological Sciences 271, 97-105.

Geiler, K. A. and Harrison, R. G. (2010): A $\Delta 11$ desaturase gene genealogy reveals two divergent allelic classes within the European corn borer (Ostrinia nubilalis). BMC Evolutionary Biology 10, 112, http://www. biomedcentral.com/1471-2148/10/112

Kim, H. and Lee, S. (2008): Molecular systematics of the genus Megoura (Hemiptera: Aphididae) using mitochondrial and molecular DNA and DNA sequences. Molecular and Cells 25, 510-522.

Király, L. and Szőcs, G. (2009): Diagnostic marker for E- and Z-strains of Ostrinia nubilalis, expressing differentially in larval $\Delta 11$ desaturase transcript. J. Appl. Entomol. 133, 272-277.

Kochansky, J., Cardé, R. T., Liebherr, J. and Roelofs, W. L. (1975): Sex pheromone of the European corn borer, Ostrinia nubilalis (Lepidoptera, Pyralidae), in New York. J. Chemical Ecology 1, 225-231.

Lassance, J-M. (2016): The European corn borer Ostrinia nubilalis. Exotic pest and model system to study pheromone evolution and speciation. In: J. D. Allison and R. T. Cardé (eds): Pheromone Communication in Moths: Evolution, Behavior and Application. Chapter fifteen. University of California Press, Oakland, California, pp. 233-244.

Lassance, J-M., Groot, A. T., Liénard, M. A., Antony, B., Borgwart, C., Andersson, F., Henderström, E., Heckel, D. and Löfstedt, C. (2010): Allelic variation in a fatty-acyl reductase gene causes divergence in moth sex pheromones. Nature 466, 486-489.

Lassance, J-M., Bogdanowicz, S. M., Wanner, K. W., Löfstedt, C. and Harrison, R. G. (2011): Gene genealogies reveal differentiation at sex pheromone olfactory receptor loci in pheromone strains of the European corn borer, Ostrinia nubilalis. Evolution 65, 1583-1593.

Lehmhus, J., Cordsen-Nielsen, G., Söderlind, C., Szőcs, G., Lassance, J-M., Fodor, J. and Künstler, A. (2012): First records of the Z-Race of European Corn Borer Ostrinia nubilalis (Hübner, 1796) from Scandinavia. J. Kulturpflanzen 64, 163-167.

Loxdale, D. and Lushai, G. (1998): Molecular markers in entomology. Bulletin of Entomological Research 88, 577-600.

Malausa, T. H., Leniaud, L., Martin, J-F., Audiot, Ph., Bourguet, D., Ponsar, S., Lee, S-F., Harrison, R. G. and Dopman, E. (2007): Molecular differentation at noclear loci in French host races of the European corn borer (Ostrinia nubilalis). Genetics 176, 2343-2355.

Moritz, G., Paulsen, M., Delker, C., Picl, S. and Kumm, S. (2001): Identification of thrips using IST-RFLP analysis. In: Proceedings of $7^{\text {th }}$ International Symposium of Thysanoptera. Reggio Calabria, Italy, pp. 365-367.

Nagy, B. (1970): Rearing of the European corn borer (Ostrinia nubilalis) on a simplified artificial diet. Acta Phytopathol. Academiae Scientiarum Hung. 2, 73-79.

Pelozuelo, L., Malosse, C., Genestier, G., Guenego, H. and Frerot, B. (2004): Host-plant specialization in pheromone strains of the European corn borer Ostrinia nubilalis in France. J. Chemical Ecology 30, 335-352. 
Peña A., Arn H., Buser H. R., Rauscher S., Bigler F., Brunetti R., Maini S. and Tóth M. (1988): Sex pheromone of European corn borer, Ostrinia nubilalis: Polymorphism in various laboratory and field strains. J. Chemical Ecol. 14, 1359-1366.

Pronko, A. V. (2011): European corn borer (Ostrinia nubilalis Hbn.) incidence in European countries and Belarus. http://agris.fao.org/agris-search/search.do?recordID=BY2012-000267

Rak-Cizej M., Cilenšek A. and Persolja J. (2014): Monitoring the European corn borer (Ostrinia nubilalis Hübner) on hops (Humulus lupulus L.) with sex pheromone traps in Slovenia. Pheromones and other semiochemicals. IOBC-WPRS Bulletin 99, 129-132.

Roelofs, W. L., Liu, W., Hao, G., Jiao, H., Rooney, A. P. and Linn, C. E. (2002): Evolution of moth sex pheromones via ancestral genes. Proc. of the National Academy of Sciences of U.S.A. 99, 13621-13626.

Sambrook, J., Fritsch, E. F. and Maniatis, T. A. (1989): Molecular Cloning: A Laboratory Manual. Cold Spring Harbor Laboratory Press, Cold Spring Harbor, New York, 397 p.

Schmitz, G. (1999): Phytophagous arthropod fauna (Acari, Insecta) of the mugwort species Artemisia vulgaris (Asteraceae) in Central Europe. Entomologia Generalis 24, 145-160.

Stewart, J. B. and Beckenbach, A. T. (2005): Insect mitochondrial genomics: the complete mitochondrial genome sequence of the meadow spittlebug Philaneus spumarius (Hemiptera: Auchenorrhyncha: Cercopoidae). Genome 48, 46-54.

Szőcs, G. and Babendreier, D. (2011): Analysis of questionnaire regarding pheromone traps for the Z-pheromone strain of European corn borer. IWGO Newsletter 31, 4-7.

Voigt, K. and Wöstemeyer, J. (2000): Reliable amplification of actin genes facilitates deep-level phylogeny. Microbiological Research 155, 179-195.

Xue, B., Rooney, A. P., Kajikawa, M., Okada, N. and Roelofs, W. L. (2007): Novel sex pheromone desaturases in the genomes of corn borers generated through gene duplication and retroposon fusion. Proc. of the National Academy of Sciences of USA 104, 4467-4472.

This is an open-access article distributed under the terms of the Creative Commons Attribution 4.0 International License (https://creativecommons.org/licenses/by/4.0/), which permits unrestricted use, distribution, and reproduction in any medium, provided the original author and source are credited, a link to the CC License is provided, and changes - if any - are indicated. (SID_1) 